\title{
KELOMPOK KERJA \& KOMUNIKASI DALAM ORGANISASI
}

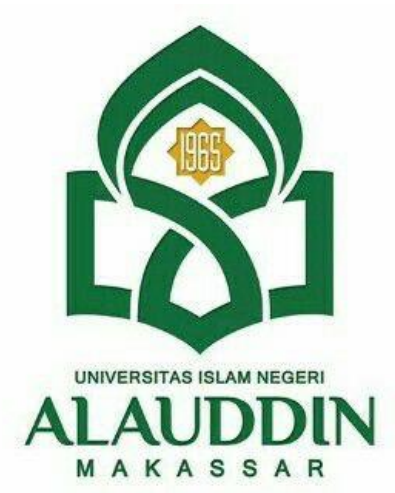

MAKALAH

Diseminarkan Pada Mata Kuliah Pengantar Manajemen Program Studi Perbankan Syariah Semester I Tahun 2021

Oleh :

Muh. Irwan Arfin

NIM. 90500121031

Dosen Pengajar:

Dra. Hj. Nuraeni Gani. MM

PROGRAM STUDI PERBANKAN SYARIAH FAKULTAS EKONOMI DAN BISNIS ISLAM UIN ALAUDDIN MAKASSAR

2021 
KATA PENGANTAR

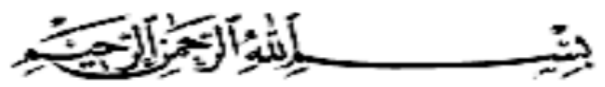

Puji syukur kehadirat Allah SWT yang telah memberikan rahmat dan hidayah-Nya sehingga saya dapat menyelesaikan tugas makalah yang berjudul Kelompok Kerja Dan Komunikasi Dalam Organisasi ini tepat pada waktunya.

Adapun tujuan dari penulisan dari makalah ini adalah untuk memenuhi tugas Dra. Hj. Nuraeni Gani. MM. pada bidang studi Pengantar Manajemen. Selain itu, makalah ini juga bertujuan untuk menambah wawasan tentang Kelompok Kerja Dan Komunikasi Dalam Organisasi dan juga bagi penulis.

Saya mengucapkan terima kasih kepada ibu Dra. Hj. Nuraeni Gani. MM. selaku Dosen bidang studi Pengantar Manajemen yang telah memberikan tugas ini sehingga dapat menambah pengetahuan dan wawasan sesuai dengan bidang studi yang saya tekuni.

Saya menyadari, makalah yang saya tulis ini masih jauh dari kata sempurna. Oleh karena itu, kritik dan saran yang membangun akan saya nantikan demi kesempurnaan makalah ini.

Bulukumba, 16 Desember 2021

Muh. Irwan Arfin 


\section{DAFTAR ISI}

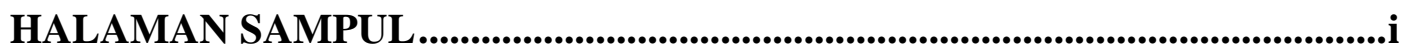

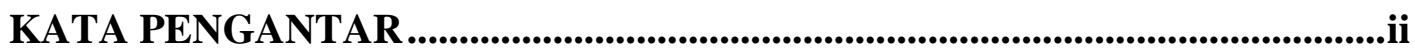

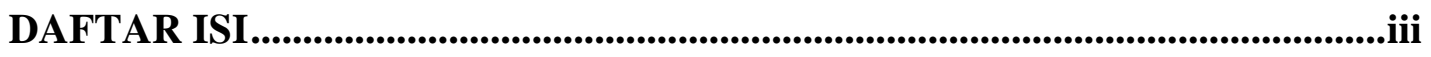

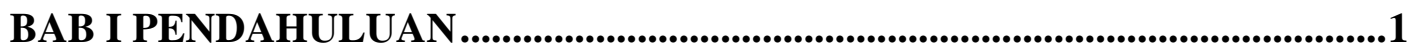

A. Latar Belakang ..........................................................................

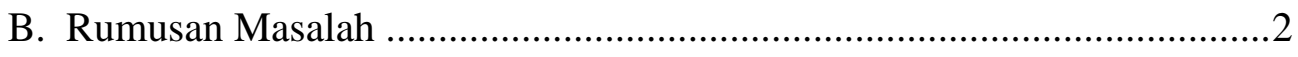

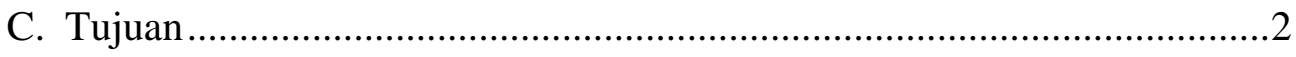

BAB II PEMBAHASAN ..................................................................................3

A. Pengertian Kelompok dan Kelompok Kerja......................................... 3

B. Ciri-ciri Kelompok Kerja..........................................................

C. Pembagian Kelompok Kerja............................................................6

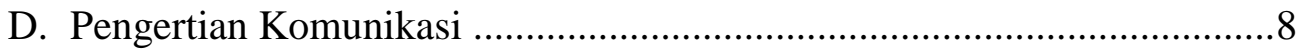

E. Jenis-Jenis Komunikasi Dalam Organisasi......................................... 10

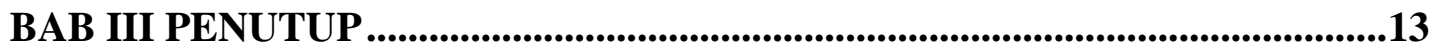

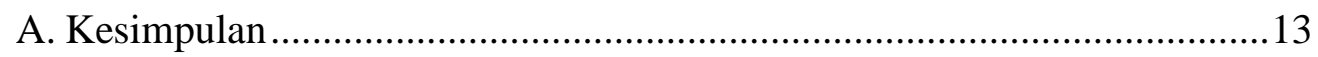

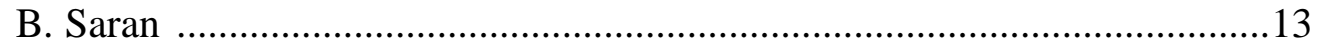

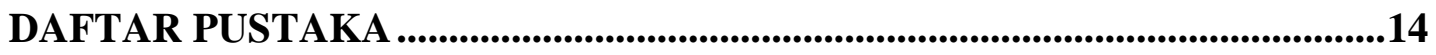




\section{BAB I \\ PENDAHULUAN}

\section{A. Latar Belakang}

Kelompok kerja dan komunikasi sebagai salah satu kunci agar fungsi implementasi dan pengarahan dapat berjalan secara efektif. Perlu disadari bahwa organisasi adalah kumpulan orang-orang atau kumpulan individu dengan berbagai karakteristik motif dan potensi. Ketik tujuan hendak dicapai, maka setiap individu perlu menyadari bahwa selain dirinya merupakan individu yang memiliki motif, namun juga merupakan bagian dari sebuah kelompok atau kumpulan, yaitu organisasi. Pada intinya kelompok kerja disusun agar keragaman individu dapat menjadi potensi yang terintegrasi dalam pencapaian tujuan, dan bukan malah sumber konflik yang akan menghambat dalam pencapaian oraganisasi. Oleh karena itu, selain kelompok kerja perlu disusun, faktor komunikasi antar pekerja, antar pemimpin dan bawahan, dan antar bagian dalam organisasi juga menentukan bagaimana kelompok kerja dapat berjalan secara efektif. Akhirnya,dengan keragaman potensi individu,pola kepemimpinan yang sesuai, kelompok kerja yang tangguh, serta komunikasi yang berjalan secara efektif, fungsi implementasi dan pengarahan dari rencana yang telah disusun barangkali tidaklah menjadi sesuatu yang sulit untuk dijalankan, sehingga tujuan akan lebih mudah dicapai secara efektif dan efisien. 


\section{B. Rumusan Masalah}

Berdasarkan latar belakang yang telah penulis uraikan, maka pokok masalah yang diangkat dalam penelitian ini adalah:

1. Apa pengertian kelompok?

2. Apa pengertian kelompok kerja?

3. Apa saja ciri-ciri kelompok kerja?

4. Apa saja pembagian kelompok kerja?

5. Apa pengertian komunikasi?

6. Apa saja jenis-jenis komunikasi dalam organisasi?

\section{Tujuan}

Berdasarkan latar belakang seperti diatas maka akan timbul beberapa tujuan penelitian sebagai berikut :

1. Untuk Memenuhi Tugas Pengantar Manajemen

2. Untuk memberikan pengetahuan kepada pembaca 


\section{BAB II}

\section{PEMBAHASAN}

\section{A. Pengertian Kelompok dan Kelompok Kerja}

Kelompok adalah sekumpulan orang yang mempunyai tujuan bersama yang berinteraksi satu dengan yang lain untuk mencapai tujuan bersama, mengenal satu dengan yang lain, dan memandang mereka sebagai bagian dari kelompok tersebut (Mulyana, 2007).

DeVito (2002) mendefinisikan kelompok sebagai kumpulan perorangan yang relatif kecil yang masing-masing dihubungkan oleh beberapa tujuan yang sama dan mempunyai derajat organisasi tertentu di antara mereka. Menurut Syamsu et al. (1999) kelompok itu adalah kumpulan dua orang atau lebih, yang secara intensif dan teratur selalu mengadakan interaksi sesama mereka untuk mencapai tujuan bersama yang telah ditetapkan, dan secara sadar mereka merasa bagian dari kelompok, yang memiliki sistem norma tertentu, peranan, struktur, fungsi dan tugas dari masing-masing anggota kelompok untuk mencapai tujuan bersama.

Kelompok menurut Slamet (2003) adalah dua atau lebih orang yang berhimpun atas dasar adanya kesamaan, berinteraksi melalui pola/struktur tertentu guna mencapai tujuan bersama, dalam kurun waktu yang relatif panjang. Kemudian Syamsu et al. (1999) mengutip pendapat Gerungan (2004) yang mendefinisikan kelompok sebagai kesatuan sosial yang terdiri atas dua atau lebih individu yang mengadakan interaksi sosial yang cukup intensif dan 
teratur, sehingga di antara individu terdapat pembagian tugas, struktur, normanorma tertentu yang khas bagi kesatuan sosial tersebut. Pendapat lain seperti Koentjaraningrat (1990) dalam Soekanto (2009) menyatakan bahwa suatu kelompok merupakan suatu masyarakat kecil yang saling berinteraksi antar anggotanya yang diatur oleh adat istiadat dan sistemsistem norma tertentu secara kontinyu serta adanya rasa identitas yang mempersatukan semua anggotanya.

Menurut Robbins (2004) Kelompok kerja adalah kelompok yang terdiri dari dua atau lebih orang yang saling mempengaruhi dan saling tergantung yang datang bersama- sama untuk mencapai sasaran tertentu. Menurut Stoner, Freeman, dan Gilbert (1995), kelompok adalah kumpulan dua orang atau lebih yang saling berinteraksi dan saling memengaruhi untuk suatu tujuan tertentu yang dipahami bersama. Kelompok memiliki karakteristik, yaitu merupakan kumpulan yang beranggotakan lebih dari satu orang (berarti adanya karakteristik yang berbeda dari setiap orang), adanya interaksi di antara kumpulan orang tersebut, dan adanya tujuan bersama yang ingin dicapai. Kelompok kerja dapat didefinisikan sebagai kelompok yang disusun oleh organisasi dengan tujuan untuk menjalankan berbagai pekerjaan yang terkait dengan pencapaian tujuan organisasi.

\section{B. Ciri-Ciri Kelompok Kerja}

Sebagai bagian penting dalam masyarakat, kelompok mempunyai ciricirinya tersendiri yang membedakan dari organisasi lain yang ada dalam 
masyarakat. Mardikanto (dalam Andarwati, dkk, 2012) menyatakan bahwa kelompok memiliki ciri-ciri antara lain yaitu adanya ikatan yang nyata, interaksi dan interelasi sesama anggotanya, struktur dan pembagian tugas yang jelas, kaidah-kaidah atau norma-norma tertentu yang disepakati bersama dan keinginan serta tujuan yang sama.

Sedangkan menurut Sherif (Gerungan, dalam Stanislaus, 2009:13) mengatakan bahwa untuk bisa dikatakan sebagai kelompok setidaknya harus memenuhi syarat sebagai berikut :

1. Adanya dorongan/motif yang sama pada individu sehingga terjadi interaksi sosial sesama dan tertuju dalam tujuan yang sama.

2. Adanya reaksi dan kecakapan yang berbeda di anatar individu satu dengan yang lain akibat terjadinya interksi sosial.

3. Adanya pembentukan dan penegasan struktur kelompok yang jelas, terdiri dari peranan dan kedudukan yang berkembang dengan sendirinya dalam rangka mencapai tujuan bersama.

4. Adanya penegasan dan peneguhan norma-norma pedoman tingkah laku anggota kelompok yang mengatur interkasi dan kegiatan anggota kelompok dalam menganalisa tujuan kelompok.

Berdasarkan apa yang diungkapkan diatas kelompok memiliki ciri-ciri, yaitu adanya interaksi dan keterikatan antar anggota, terdapat struktur kelompok yang jelas, adanya keinginan dan tujuan yang ingin dicapai, memiliki norma yang mengatur jalannya kelompok, dan anggota mempersepsikan dirinya sebagai bagian dari kelompok. 


\section{Pembagian Kelompok Kerja}

1. Kelompok kerja formal,

Kelompok kerja formal adalah kelompok kerja yang dibentuk atau disusun secara resmi oleh manajer di mana kelompok kerja tersebut diberikan tugas dan pekerjaan yang terkait dengan pencapaian tujuan organisasi. Dapat berupa kelompok kerja langsung, kepanitiaan, dan kelompok kerja temporal/khusus.

Kelompok formal adalah suatu kelompok yang sengaja dibentuk untuk melaksanakan suatu tugas tertentu. Anggota anggotanya biasanya diangkat oleh organisasi. Tetapi itu tidak harus seperti itu pada setiap kasus. Sejumlah orang yang ditetapkan untuk melaksanakan suatu tugas tertentu merupakan bentuk dari kelompok formal ini.contohnya komite atau panitia, unit-unit kerja seperti unit bagian, laboratorium riset dan pengembangan, tim manajer, kelompok tukang pembersih, dan sebagainya. $^{1}$

Kelompok formal adalah kelompok yang mempunyai peraturan tegas dan sengaja diciptakan oleh anggota-anggotanya untuk mengatur hubungan antar sesamanya. ${ }^{2}$

Robbins dan Judge, menjelaskan bahwa kelompok formal bersetruktur organisasi, dengan desain penugasan, dan penentuan tugas.dalam hal ini peerilaku anggota yang terikat di dalamnya di tentukan

\footnotetext{
${ }^{1}$ Arsyadana, A. (2019). Dasar-Dasar Perilaku Kelompok dan Memahami Tim Kerja dalam Lembaga Pendidikan Islam. Prosiding Nasional, 2, 213-232.

${ }_{2}^{2}$ Mulyanah, D. (2016). Tahap Perkembangan Kelompok Informal (Doctoral dissertation, Universitas Negeri Semarang).
} 
dan di arahkan pada tujuan organisasi. Sedangkan dalam kelompok informal, terbentuk secara alamiah sebagai tanggapan dan atas kebutuhan akan adanya kontak sosial. Berdasarkan penjelasan Robbins dan Judge tersebut berarti perilaku dari anggota organisasi terikat oleh organisasi, karena semua penugasan dan wewenang telah di tentukan oleh organisasi untuk mencapai tujuan organisasi.

2. Kelompok Kerja Informal

Kelompok kerja informal adalah kelompok kerja yang disusun atau tersusun dengan sendirinya ketika beberapa anggota dari organisasi yang kegiatannya biasanya tidak terkait langsung dengan rencana-rencana rutin dari organisasi, namun secara tidak langsung akan memengaruhi kinerja dari orang-orang dalam organisasi.

Kelompok informal adalah kelompok yang tidak mempunyai struktur dan organisasi tertentu atau yang pasti. Kelompok informal biasanya terbentuk karena pertemuan yang berulangkali yang didasari oleh kepentingan dan pengalaman yang sama. ${ }^{3}$

Kelompok informal adalah suatu kelompok yang tumbuh dari proses interaksi, daya tarik, dan kebutuhankebutuhan seseorang. Anggota kelompok tidak diatur dan diangkat, keanggotaan ditentukan oleh daya tarik bersama dari individu dan kelompok. Kelompok informal ini sering timbul berkembang dalam kelompok formal, karena adanya beberapa

${ }^{3}$ Mulyanah, D. (2016). Tahap Perkembangan Kelompok Informal (Doctoral dissertation, Universitas Negeri Semarang). 
anggota yang secara tertentu mempunyai nilai-nilai yang sama yang perlu ditularkan sesama anggota lainnya. Kadangkala kelompok informal berkembang atau keluar dari organisasi formal [2, p. 194]. ${ }^{4}$

Menurut Kartono (dalam Darminah, 2011:38) kelompok informal adalah sistem interelasi manusiawi berdasarkan rasa suka dan tidak suka, dalam iklim psikis yang intim, ada kontak muka berhadapan muka serta memiliki morak tinggi. Kelompok informal tidak berstatus resmi dan tidak didukung oleh peraturan-peraturan. Kelompok informal juga memiliki pembagian tugas, peranan dan hirarki tertentu, serta pedoman tingkah laku anggotanya dan konvensi-konvensinya tetapi hal itu tidak dirumuskan secara tegas dan tertulis seperti pada kelompok formal. ${ }^{5}$

\section{Pengertian Komunikasi}

Komunikasi dalam organisasi merupakan pengiriman serta penerimaan berbagai pesan organisasi baik di kelompok organisasi formal maupun informal. Komunikasi formal merupakan jalur komunikasi resmi dengan rantai komando atau hungungan tugas dan tanggung jawab yang jabatannya dalam organisasi. Dalam organisasi terdapat visi, misi, budaya dan iklim organisasi yang sangat menentukan dalam perilaku organisasi tersebut. Meskipun semua organisasi memiliki karakteristik yang khas. Semua organisasi memiliki satu

\footnotetext{
${ }^{4}$ Arsyadana, A. (2019). Dasar-Dasar Perilaku Kelompok dan Memahami Tim Kerja dalam Lembaga Pendidikan Islam. Prosiding Nasional, 2, 213-232.

${ }^{5}$ Shabrina, N. A. N. (2016). faktor-faktor Terbentuknya Kelompok Informal (Doctoral dissertation, Universitas Negeri Semarang).
} 
tujuan, satu struktur, proses untuk mengkoordinasi kegiatan dan orang-orang yang melaksanakan peran-peran yang berbeda. ${ }^{6}$

Menurut Stoner, Freeman, dan Gilbert (1995), komunikasi dapat didefinisikan sebagai proses di mana seseorang berusaha untuk memberikan pengertian atau pesan kepada orang lain melalui pesan simbolis. Komunikasi memiliki beberapa elemen penting, yaitu:

- Komunikasi melibatkan orang-orang.

- Komunikasi berarti adanya proses berbagi informasi atau pemberian informasi maupun pengertian.

- Komunikasi melibatkan simbol-symbol.

Komunikasi Organisasi merupakan bentuk pertukaran pesan antara unitunit komunikasi yang berada di dalam suatu organisasi. ${ }^{7}$ Komunikasi organisasi serupa dengan komunikasi internal. Pengertian dari komunikasi internal adalah pertukaran gagasan di antara para administrator dan karyawan dalam suatu perusahaan, dalam struktur lengkap yang khas disertai pertukaran gagasan secara horizontal dan vertikal di dalam perusahaan, sehingga pekerjaan dapat berjalan. ${ }^{8}$ Komunikasi organisasi pada umumnya membahas tentang struktur dan fungsi organisasi, hubungan antarmanusia, komunikasi dan proses pengorganisasian serta budaya organisasi. ${ }^{9}$ Komunikasi organisasi

\footnotetext{
${ }^{6}$ Yuliana, R. (2012). Peran komunikasi dalam organisasi. JURNAL STIE SEMARANG (EDISI ELEKTRONIK), 4(3), 52-58.

${ }^{7}$ Pace, R. Wayne; Faules, Don F. (1993-12-01). Organizational Communication Prentice Hall. ISBN 9780136438007. p.184

${ }^{8}$ (Indonesia)[jihadi.staff.umm.ac.id/files/2010/01/2_komunikasi_organisasi.pdf]

${ }^{9}$ Teori-teori komunikasi|pusat penerbitan universitas terbuka
} 
diberi batasan sebagai arus pesan dalam suatu jaringan yang sifat hubungannya saling bergantung satu sama lain meliputi arus komunikasi vertikal dan horizontal. ${ }^{10}$

\section{E. Jenis-jenis Komunikasi Dalam Organisasi}

Menurut Pace and Fules, terdapat beberapa jenis komunikasi terarah dalam komunikasi organisasi, sebagai berikut. ${ }^{11}$

1. Komunikasi Atasan ke Bawahan (Downward communication)

Yaitu komunikasi yang berlangsung ketika orang-orang yang berada pada tataran manajemen mengirimkan pesan kepada bawahannya. Fungsi arus komunikasi dari atas ke bawah ini adalah:

- Pemberian atau penyimpanan instruksi kerja (job instruction)

- Penjelasan dari pimpinan tentang mengapa suatu tugas perlu untuk dilaksanakan (job rationale)

- Penyampaian informasi mengenai peraturan-peraturan yang berlaku (procedures and practices)

- Pemberian motivasi kepada karyawan untuk bekerja lebih baik.

Komunikasi ke bawah sangat dibutuhkan oleh pengurus di tingkat bawah dalam melaksanakan kegiatan organisasi. Pola penyebaran

\footnotetext{
${ }^{10}$ Sendjaja, S Djuarsa.1994, Teori Komunikasi. Pusat Penerbitan Universitas Terbuka.

${ }^{11}$ Pace, R. Wayne; Faules, Don F. (1993-12-01). Organizational Communication Prentice Hall. ISBN 9780136438007. p.184
} 
informasi membawa resiko terjadinya distorsi pesan, sehingga pesan yang disampaikan ke anggota menjadi kabur atau tidak dapat ditangkap maknanya secara jelas. ${ }^{12}$

2. Komunikasi Bawahan ke Atasan (Upward Communication)

Yaitu komunikasi yang terjadi ketika bawahan (subordinate) mengirim pesan kepada atasannya. Fungsi arus komunikasi dari bawah ke atas ini adalah sebagai penyampaian informasi tentang pekerjaan ataupun tugas yang sudah dilaksanakan, penyampaian informasi mengenai persoalan-persoalan pekerjaan ataupun tugas yang tidak dapat diselesaikan oleh bawahan, penyampaian saran-saran perbaikan dari bawahan, penyampaian keluhan dari bawahan tentang dirinya sendiri maupun pekerjaannya.

Komunikasi dari bawahan kepada atasan sebenarnya sangat penting bagi kelangsungan hidup organisasi, karena atasan akan mempunyai data yang dapat dipakai untuk membuat kebijakankebijakan baru bagi organisasi. Pada kenyataannya komunikasi dari bawahan kepada atasan atau komunikasi ke atas sangat sulit dilakukan. ${ }^{13}$

\section{Komunikasi Horisontal (Horizontal Communication)}

\footnotetext{
${ }^{12}$ Gutama, T. A. (2010). Peran komunikasi dalam organisasi. Jurnal Sosiologi Dilema, 25(2), 107-113.

${ }^{13}$ Gutama, T. A. (2010). Peran komunikasi dalam organisasi. Jurnal Sosiologi Dilema, 25(2), 107-113.
} 
Yaitu komunikasi yang berlangsung di antara para karyawan ataupun bagian yang memiliki kedudukan yang setara. Fungsi arus komunikasi horisontal ini adalah untuk memperbaiki koordinasi tugas, upaya pemecahan masalah, saling berbagi informasi, upaya pemecahan konflik, dan upaya membina hubungan melalui kegiatan bersama.

4. Komunikasi Lintas Saluran (Interline Communication)

Yaitu tindak komunikasi untuk berbagi informasi melewati batasbatas fungsional. Spesialis staf biasanya paling aktif dalam komunikasi lintas-saluran ini karena biasanya tanggung jawab mereka berhubungan dengan jabatan fungsional. Karena terdapat banyak komunikasi lintassaluran yang dilakukan spesialis staf dan orang-orang lainnya yang perlu berhubungan dalam rantai-rantai perintah lain, diperlukan kebijakan organisasi untuk membimbing komunikasi lintas-saluran. 


\section{BAB III}

\section{PENUTUP}

\section{A. Kesimpulan}

Kelompok kerja dan komunikasi sebagai salah satu kunci agar fungsi implementasi dan pengarahan dapat berjalan secara efektif. Kelompok kerja dibagi menjadi 2 yaitu kelompok kerja formal dan kelompok kerja informal, dengan cakupan yang berbeda.

Komunikasi dalam organisasi merupakan pengiriman serta penerimaan berbagai pesan organisasi baik di kelompok organisasi formal maupun informal. Komunikasi formal merupakan jalur komunikasi resmi dengan rantai komando atau hungungan tugas dan tanggung jawab yang jabatannya dalam organisasi. Komunikasi dibagi menjadi 4 yaitu Komunikasi Atasan ke Bawahan, Komunikasi Bawahan ke Atasan, Komunikasi Horisontal, dan Komunikasi Lintas Saluran.

\section{B. Saran}

Demikian makalah ini kami buat sebagaimana mestinya untuk melaksanakan tugas terstruktur. Kami menyadari masih banyak kekurangan dan kesalahan dalam penulisan makalah ini. Untuk itu kritik dan saran yang bersifat membangun senantiasa kami tunggu guna perbaikan makalah ini selanjutnya semoga makalah ini dapat bermanfaat bai kita semua. 


\section{DAFTAR PUSTAKA}

Arsyadana, Addin. "Dasar-Dasar Perilaku Kelompok dan Memahami Tim Kerja dalam Lembaga Pendidikan Islam." Prosiding Nasional 2 (2019): 213-232.

Gutama, T. A. "Peran komunikasi dalam organisasi." Jurnal Sosiologi Dilema 25.2 (2010): 107-113.

https://id.wikipedia.org/wiki/Komunikasi_organisasi

Mulyanah, Dewi. Tahap Perkembangan Kelompok Informal. Diss. Universitas Negeri Semarang, 2016.

Saleh, A. "Pengertian, Batasan dan Bentuk Kelompok." (2019).

Shabrina, Nira Amalia Nur. faktor-faktor Terbentuknya Kelompok Informal. Diss. Universitas Negeri Semarang, 2016.

Yuliana, Rahmi. "Peran komunikasi dalam organisasi." JURNAL STIE SEMARANG (EDISI ELEKTRONIK) 4.3 (2012): 52-58. 